\title{
Are we throwing the baby out with the bath water?
}

\author{
Robert W. Emery, MD, ${ }^{\mathrm{a}}$ and Christopher C. Krogh, $\mathrm{BSN}^{\mathrm{b}}$
}

\footnotetext{
$\overline{\text { From }{ }^{\mathrm{a}} \text { Division }}$ of Cardiothoracic Surgery, St Joseph's Hospital and Medical Center, St Paul, Minn; and bepartment of Surgery, University of Maryland Medical Center, Baltimore, Md. Disclosures: Authors have nothing to disclose with regard to commercial support.

Received for publication March 8, 2016; accepted for publication March 10, 2016; available ahead of print April 23, 2016.

Address for reprints: Robert W. Emery, MD, St Joseph's Hospital and Medical Center, 45 10th St., Division of Cardiothoracic Surgery, St Paul, MN 55101 (E-mail: remery1513@aol.com).

J Thorac Cardiovasc Surg 2016;152:118-9

$0022-5223 / \$ 36.00$

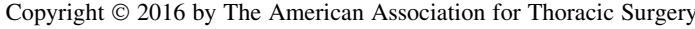

http://dx.doi.org/10.1016/j.jtcvs.2016.03.042
}

In the current era of increased use of bioprosthetic valves and a dramatic rise in the application of transcatheter aortic valve replacement (AVR)/implantation, in this issue of the Journal, Ogawa and colleagues ${ }^{1}$ provide data that add to the armamentarium for treating aortic stenosis in very elderly individuals. With a longer-living population, life-long protection from reoperation is necessary. ${ }^{2}$ Although reoperation generally can be performed with acceptable mortality, this might not be the case in very elderly patients, at 15 to 20 years after AVR. Furthermore, most published studies of reoperation have not addressed the significant morbidity associated with reoperation in elderly patients, or the associated expenses, prolonged recovery, and burden on families.

Owing to the need for life-long anticoagulant therapy, mechanical AVR is little used in patients aged $>80$ years, yet these individuals may have many more years of life in some societies. Are these issues worth the trade-off for chronic anticoagulation?

Those elderly patients with a small body surface area subjected to biological AVR have the risk with the inherent and probable impact of patient-prosthesis mismatch, that of adding a more complex annular enlargement procedure or the need for life-long anticoagulation at some point. As noted by the authors, patientprosthesis mismatch was rare in this group undergoing AVR with the St Jude Regent valve, consistent with previous reports. ${ }^{2}$

Although this experience is small, and no conclusions can be drawn, the complications of anticoagulation were minimized when lower international normalized ratio target ranges, the use of aspirin, and access to modern health care were applied. In fact, the most lethal valve-related event, hemorrhage, was more common in the biological AVR group. Nevertheless, it is known that nearly one-half of valve-related hemorrhagic events of follow-up. applicable.

\section{References} $18-25$

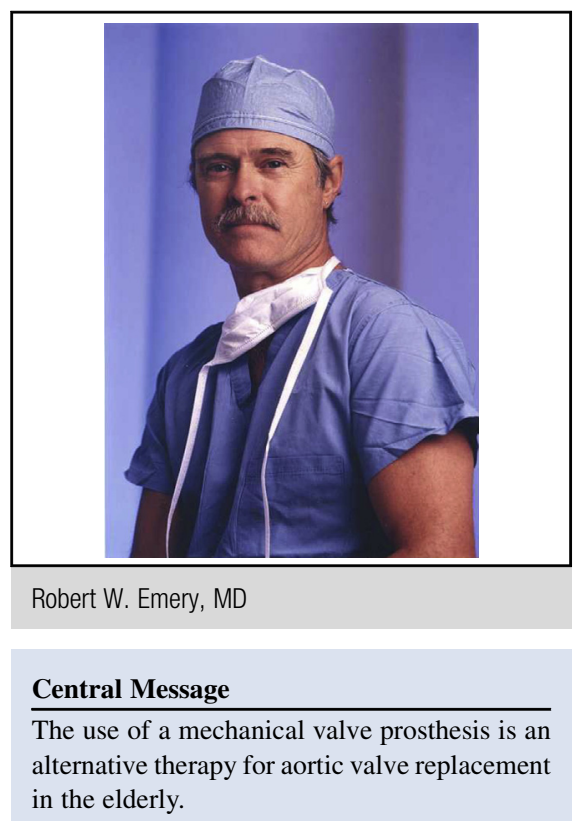

See Article page 112 .

seen after 25 years of follow-up occur in the first year after surgery. ${ }^{2}$ The addition of home monitoring also should be of benefit over time, as should individualizing the anticoagulation regimen. ${ }^{3,4}$

Surprisingly, in this study, ${ }^{1}$ thromboembolism was more common with mechanical AVR, but $75 \%$ of the events were minor. ${ }^{5}$ Valve-related mortality was absent in the first year

Given the inherent limitations of this report, the use of the 17-mm Regent valve served the population well, with improvement in symptoms and patient safety. The use of such a small prosthesis in adults is uncommon, but should be considered in patients for whom this is

1. Ogawa T, Onoe M, Moriwaki S, Shioji K, Iwamuro A, Uegaito T, et al. Aortic valve replacement with a $17-\mathrm{mm}$ mechanical prosthesis in octogenarian or older patients. J Thorac Cardiovasc Surg. 2016;152:112-7.

2. Emery RW, Krogh CC, Arom KV, Emery AM, Benyo-Albrecht K, Joyce LD, et al. The St Jude Medical cardiac valve prosthesis: a 25-year experience with single valve replacement. Ann Thorac Surg. 2005;79:776-83.

3. Emery RW, Emery AM, Raikar GV, Shake JG. Anticoagulation for mechanical heart valves: a role for patient-based therapy. J Thromb Thrombolysis. 2008;25: 
4. Koertke H, Zittermann A, Wagner O, Ennker J, Saggau W, Sack FU. Efficacy and safety of very low dose self-management of oral anticoagulation in patients with mechanical heart valve replacement. Ann Thorac Surg. 2010;90:1487-94.
5. Khan S, Trento A, DeRobertis M, Kass RM, Sandhu M, Czer L, et al. Twenty-year comparison of tissue and mechanical valve replacement. J Thorac Cardiovasc Surg. 2001;122:257-69.

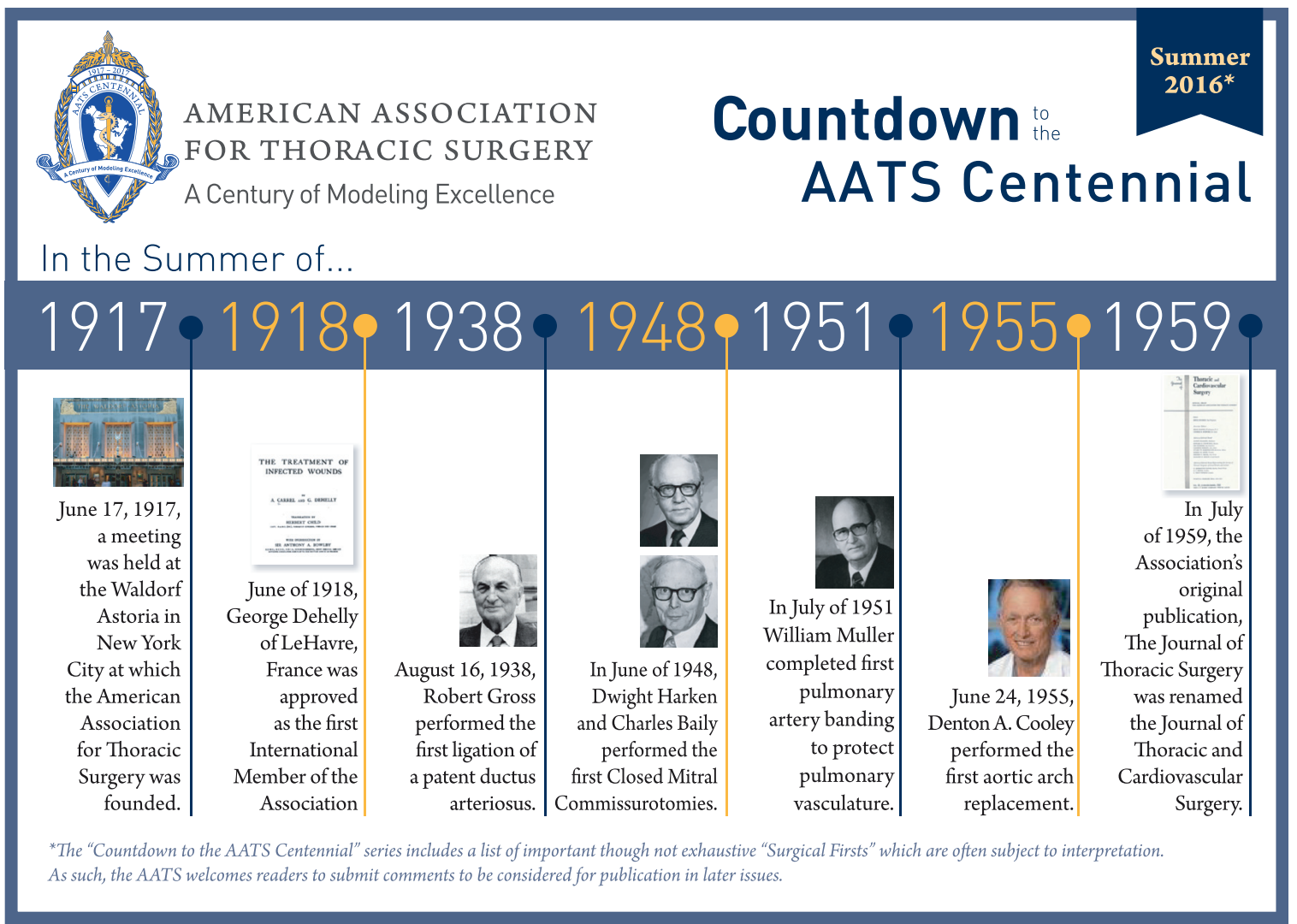

